enteurs du pouvoir"”. Na dłuższą metę, jak okazało się 9 termidora, instancją decydującą politycznie pozostał Konwent Narodowy. Nikt nie neguje, że w sensie prawnym jedynie Konwent wchodził w rachubę. Komisarze ludowi od niego wywodzili swoje pełnomocnictwa, powoływali się na jego toutepuissance, kiedy stawiano im na prowincji śmieszny, jak mówili, zarzut braku podziału władzy; cała ich działalność polegała tylko na tym, by uzyskać władzę Konwentu i w sytuacjach krytycznych, kiedy bez szczególnego polecenia działali na własne ryzyko, jak w przypadku zdrady Dumourieza, powoływali się oni wyłącznie na autorytet Konwentu. On zawsze zachowuje impulsion. Cały autorytet państwa, który z taką bezpośredniością i brakiem hamulców rozwinął się w latach 1792-1795 we Francji, miał swoje źródło w Konwencie Narodowym, „emanował” z niego, jak lubiono wówczas powtarzać, a jego pełnomocnictwa były bezpośrednimi emanacjami uznanej przez niego pouvoir constituant.

PRZEŁOŻY A KINGA MARULEWSKA

$\infty$

JAKUB CHMIELNIAK

Wydział Polonistyki UJ, Instytut Studiów Regionalnych UJ

\title{
Epoka techniki, pokoju i depolityzacji: wstęp do lektury Carla Schmitta
}

\begin{abstract}
arl Schmitt (1888-1985) należy do grona myślicieli, których nazwiska elektryzują, a prace stanowią nieprzerwaną intelektualną stymulację dla kolejnych pokoleń czytelników. Zarazem pozostaje on człowiekiem, którego idee były i są w znacznym stopniu wykorzystywane do prokurowania wzajemnej krytyki przez intelektualistów z obu stron sceny politycznej, co utrudnia ich pełny odbiór i całkowite zrozumienie. Problematyczność, jak się wydaje, wynika z niepełnej analizy moralno-egzystencjalnych przesłanek, które pobudzały niemieckiego prawnika do poszukiwań intelektualnych. Od-
\end{abstract}

wręcz dyktatorskiej władzy państwowej" (R. Hübner, Die parlamentarische Regierungsweise Englands, Tübingen 1918, s. 38) i następnie, z racji tego, że „pełnomocnik co do siły przerósł swego zleceniodawcę", a pierwszy minister zajmował kluczową pozycję, mówić o jego „nieukrywanej dyktaturze”.

prawdziwymi posiadaczami władzy (fr.) 
czytany powierzchownie i w sposób z góry zakładający użycie jego ustaleń do własnych celów, jawi się, jak pokażemy niżej, jako myśliciel stricte nowoczesny albo jako prawicowy teoretyk państwa prawa. Głębsza analiza ukazuje myślenie Schmitta jako wyraz głębokiego przejęcia kryzysem naszych czasów, zakładającego rozpoznanie nieludzkiego, albo nawet diabolicznego wymiaru tegoż kryzysu. Owo kłopotliwe położenie rozpatrywane przez Schmitta należy osobliwie rozpatrywać w odwołaniu do pojęć: neutralizacji, technicyzacji, pacyfikacji, apolityzacji i uniwersalizacji współczesnego państwa i społeczeństwa. Punkt zapalny, jego zdaniem, znaleźć możemy w teorii Thomasa Hobbesa, zawartej w książce Leviathan, która nie tyle nawet antycypowała charakter instytucjonalny nowoczesnego państwa, ile stanowiła kluczowy impuls w dziele zaprogramowania jego początku, drogi rozwoju i celu. Historyczno-filozoficzna interpretacja, której poddane zostało dzieło Hobbesa, wraz z innymi pismami autora Nomos der Erde zawartymi w zbiorze Teologia polityczna i inne pisma, w ramach perspektywy proponowanej w niniejszym artykule, która kładzie nacisk raczej na pełny odbiór, biorący pod uwagę także motywacje moralno-egzystencjalne Schmitta, być może pozwoli nam odsłonić rzeczywisty poziom refleksji zajmującego nas myśliciela, który sytuuje się nie tyle na poziomie krytyki liberalizmu czy apologii nowoczesnego państwa, ile na poziomie pewnego sposobu ujęcia problemu teologiczno-politycznego, który w tym wypadku zostaje sprowadzony do walki dobra ze złem, Boga z Antychrystem.

Jak powiedzieliśmy, istnieje zasadniczy problem związany z właściwym rozumieniem Schmitta. W opinii lewicowych intelektualistów niemiecki prawnik był „radykalnym (jeśli nawet prawicowym) demokratą”, którego krytyka liberalizmu i związanej z nim neutralizacji postrzegana jest jako „zdemaskowanie dominacji w społeczeństwach liberalnych" ${ }^{29}$. Jak wskazuje inny badacz, John McCormick, ,akademicka lewica, na przykład Chantal Mouffe, doszukuje się u Schmitta teorii państwa zdolnej wypełnić polityczną pustkę w sercu tradycyjnego marksizmu" , a ,wielu liberałów i demokratów, w tym Stephen Holmes i Jürgen Habermas, na podstawie pism Schmitta broni rzekomo niezmiennie aktualnych założeń oświeceniowej racjonalności”" ${ }^{31}$. Zupełnie inaczej brzmią głosy pochodzące z drugiej strony politycznej sceny. Prawicowcy widzą w Schmitcie teoretyka nowoczesnego państwa prawa, który żywi przekonanie, że „idee, na których wydaje się opierać liberalizm indywidualizm, prawa człowieka, rządy prawa - to fikcje i że rzeczywiste

Zob. M. Lilla, Lekkomyślny umysł, przeł. J. Margański, Warszawa 2006, s. 59.

J. McCormick, Irracjonalny wybór i krwawa walka. Wprowadzenie do teorii Carla Schmitta, przeł.

A. Warso, „Kronos” 2008, nr 3, s. 78.

Tamże, s. 78-79. 
fundamenty narodowego życia politycznego - jedność, przywództwo, autorytet, arbitralne decyzje - są nieliberalne" ${ }^{32}$. McCormick wymienia najważniejsze postaci, które widzą Schmitta w szatach konserwatysty: Heinricha Meiera ${ }^{33}$ czy też małżeństwo Cathrine i Michaela Zuckertów, ${ }^{34}$ którzy „przeciwstawiają nihilistyczny - ich zdaniem - i autorytarny model Schmittiański poglądom Straussa, które uznają za bardziej liberalne, w większym stopniu zorientowane filozoficznie i moralnie" ${ }^{35}$. Na gruncie polskim Schmitta komentowali m.in. związani z warszawskim „Kronosem” Krzysztof Michalski, Piotr Nowak i Piotr Graczyk. W jednym z tekstów tego ostatniego możemy znaleźć - zapowiadające odważny dyskurs teologiczno-polityczny - sformułowania mówiące o tym, że „Schmitt jest katolikiem, a konkretnie katolickim apokaliptykiem" ${ }^{36}$. Niniejszy artykuł nie zakłada żadnego z wymienionych podejść badawczych. Schmitt, gdy pozwolimy mu przemówić własnym głosem, a na jego spuściznę spojrzymy z życzliwością i w całej jej różnorodności i złożoności - jak wskazaliśmy: nie tylko intelektualnej, ale i moralnoegzystencjalnej - sam wystawi sobie odpowiednie referencje. Tematem pozostaje poszukiwanie jego prawdziwych opinii na temat nowoczesnego państwa.

Chociaż autor Nomos der Erde kojarzy się przede wszystkim z artykułem pt. Pojęcie polityczności, w którym nakreślone zostaje rozróżnienie, z którego stał się najbardziej znany - czyli dychotomia przyjaciela i wroga, to przejdziemy do niego w dalszym ciągu tekstu, na początek proponując pochylenie się nad książką będącą par excellence wykładem z historii idei. Lewiatan w teorii państwa Thomasa Hobbesa, bo o tę pozycję chodzi, pozwala w pełni zrozumieć tak charakter, jak i konsekwencje precedensu w dziejach ludzkości, jakim jest powstanie nowoczesnego państwa. Wyrażone tam opinie zestawimy $\mathrm{z}$ esejami ze zbioru Teologia polityczna $i$ inne pisma oraz z artykułem Epoka neutralizacji i polityzacji, który w wydaniach niemieckich traktowany jest jako komplementarny wobec Pojęcia polityczności. Czyni tak choćby Leo Strauss w swoich Uwagach do „Pojęcia polityczności” Carla Schmitta, gdzie na początku i na końcu cytuje fragment tekstu niemieckiego prawnika - który pominięty został przez polskiego wydawcę, co może utrudniać pełne zrozumienie myśli niemieckiego prawnika. Do komentarza Straussa również odniesiemy się po analizie Lewiatana...

M. Lilla, Lekkomyślny..., s. 58.

Zob. H. Meier, Carl Schmitt \& Leo Strauss: The Hidden Dialogue, przeł. J. H. Lomax, Chicago 1995.

Zob. C. Zuckert, M. Zuckert, The Truth About Leo Strauss: Political Philosophy and American Democracy, Chicago 2006.

J. McCormick, Irracjonalny wybór..., s. 79.

P. Graczyk, Komentarz do uwagi Straussa o Schmitcie, „Kronos” 2008, nr 3, s. 77. 
Książka, choć podzielona na siedem rozdziałów, ma dwie zasadnicze części, które nazwać można filologiczną (rozdziały 1 i 2) i filozoficznopolityczną (rozdziały 3-7). W pierwszej z nich (ta mniej nas interesuje) Schmitt nawiązuje do samej figury Lewiatana, wskazując na jego teologiczno-chrześcijańskie i kabalistyczno-żydowskie interpretacje. Dowiadujemy się m.in. o diabelskiej proweniencji mitycznej figury morskiego potwora, choć „utożsamienie z diabłem” i „pomieszanie Lewiatana z figurami apokaliptycznymi” ${ }^{37}$ nie leży u podstaw jej rozumienia, tylko jest efektem refleksji późniejszej. Jeszcze w XII wieku, w gandawskim Liber floridus, „Antychryst króluje na Lewiatanie, który określony jest jako serpens [wąż] i przedstawiony w postaci wielkiej ryby, oznacza zatem tyle co «świat» i nie jest figurą apokaliptyczną" ${ }^{38}$. Byłby tedy Lewiatan nie samym diabłem, ale podstawą jego władania, choć niezmiennie czymś „złym i wrogim”, istotą, która - jak choćby w doktrynie mandejczyków - „na końcu świata połyka kosmos”. ${ }^{39}$. Czynione jeszcze przez Leona Wielkiego i Grzegorza z Nyssy tego typu interpretacje z czasem uległy wypaczeniu i pauperyzacji. Przełomowy moment na końcu drugiego rozdziału zostaje uściślony: chodzi o wiek XIII ${ }^{40}$. I choć jeszcze około roku 1500, co widać na przykład w dziełach Hieronima Boscha, „nadal obowiązuje średniowieczna wiara w demony”, a ,jego diabły są ontologiczną realnością" ${ }^{41}$, to już w wieku XVI - bezpośrednio przed epoką Hobbesa - „obraz traci swą właściwą moc demoniczną. Umierają średniowieczne wierzenia, żywe jeszcze w pismach Lutra; złe duchy zmieniają się w groteskowe, a nierzadko zabawne upiory" ${ }^{42}$. "Literacki koncept” Hobbesa, jak nazywa go Schmitt, mógł zaistnieć dopiero w wyniku owej zmiany znaczenia.

Lewiatan Hobbesa, jak już powiedzieliśmy, diabłem nie jest. To wielki człowiek, agregat złożony z setek i tysięcy innych ludzi. Jak pisze Hobbes, „he is inabled to form the wills of them all" - to nie tylko suma ciał, lecz także suma woli: coś, co zostanie później nazwane przez Jana Jakuba Rousseau wolą powszechną - wolą ogółu. Zaś groza, jaką wzbudza dlatego, że posiada

C. Schmitt, Lewiatan w teorii państwa Thomasa Hobbesa, przeł. M. Falkowski, Warszawa 2008, s. 16.

Tamże. Podkreślenie - J. Chmielniak.

Tamże.

Czytamy w przypisie 24 na stronie 40, że „symbole, żywe w XIII wieku, od wieku XIV stają się coraz mniej widoczne, by znikać bez śladu od wieku XVI". Ciężko powiedzieć, o jaki przełom może chodzić Schmittowi. Na ten czas przypada wiele zmian, m.in. szczególnie intensywny wybuch sporu o uniwersalia - i związane z nim potępienie 219 tez, w tym tez św. Tomasza, 7 marca 1277 roku w Paryżu przez tamtejszego biskupa, Stephena Tempiera z którego ostatecznie zwycięsko wychodzi koncepcja Williama z Ockham.

Tamże, s. 36.

Tamże, s. 35. 
„the use of so much Power and Strength" ${ }^{43}$, „zmusza wszystkich do pokoju" ${ }^{44}$. Wszystko to dzięki rzekomej umowie, którą zawierają ze sobą ludzie, ażeby wyzwolić się ze stanu natury, w którym wszyscy są sobie wrodzy i każdy może bezkarnie - to wszak stan anarchii, a więc bezprawia - zabić każdego. Bellum omnium contra omnes. Punktem wyjścia jest, jak pisze Schmitt, „strach panujący w stanie natury”, zaś „celem i punktem dojścia” „bezpieczeństwo w obrębie cywilizowanego państwa”. Wykorzystując mające swe zakorzenienie w prawie rzymskim, a wprowadzone w obręb chrześcijaństwa przez Leona I Wielkiego rozróżnienie na auctoritas i potestas, Schmitt wskazuje (powołując się na niemieckich historyków: Gisberta Beyerhausa i Karla Theodora), że Lewiatan - jako „śmiertelny bóg” - jest suwerenny, a owa suwerenność, „która obowiązuje w nowoczesnym państwie prawa, zawiera w zsekularyzowanej postaci kalwińskie pojęcie Boga razem z charakterystyczną dlań zasadą legibus solutus [niezwiązany prawami]" ${ }^{46}$, czyli czystą potestas - mocą. Summa potestas, czyli najwyższa władza, utożsamiona zostaje z auctoritas. Lewiatan, niczym protestancki Bóg, jest wszechpotężny, jednak owa potęga ma inne pochodzenie - ,jest dziełem człowieka i powstaje dzięki umowie zawartej między ludźmi" ${ }^{47}$.

Początkowo przyjmuje on postać suwerena. To pierwsze stadium ewolucji od chwili, gdy moment założycielski - moment umowy - wywoła sytuację, w której jeszcze nie ma państwa, ale powstaje „anarchistyczna umowa społeczna" ${ }^{48}$. Co ciekawe, autor Teologii politycznej... zauważa, że władca wyłania się „przy okazji” jako swoisty „efekt uboczny”. Początkowo tożsamy z postacią absolutnego władcy, Lewiatan-Bóg pozostaje wszelako zewnętrzny wobec reszty ludzi, którzy „rezygnują z prawa do sprzeciwu” ${ }^{49}$. Jego absolutna moc pozostaje gwarantem spokoju i bezpieczeństwa, sprawnego funkcjonowania „mechanizmu panowania”. Zmechanizowanie aparatu władzy jest zdaniem Schmitta „istotną przesłanką ideową” do późniejszego faktu i możliwości - zaistnienia „ery techniczno-przemysłowej” ${ }^{50}$. Z tego też powodu suweren-polityk w takiej formie, jaką przyjął w wieku XVIII - czyli monarchy absolutnego - musiał zaniknąć, by wyłonić się mogły nowy mechanizm i nowy sposób sprawowania władzy. Tak czy owak, w tym momencie - chciałoby się rzec: dziejowym - Lewiatan staje się „wielką maszyną,

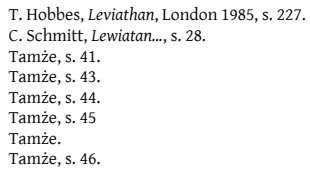


ogromnym mechanizmem, mającym zabezpieczać doczesną i fizyczną egzystencję ludzi, nad którymi panuje i których chroni" ${ }^{51}$ - ochrona ta, zwłaszcza w wieku XVI, była potrzebna w związku z czymś, co Schmitt nazywa - za Biblią - Behemotem, a co oznacza niekończące się spory (a w związku z tym i wojny) mające fundament teologiczny.

Rozwój nowoczesnej nauki ściśle związany jest z koniecznością wypracowania narzędzi, które posłużą państwu do sprawowania władzy. Wraz ze wzrostem potęgi uzbrojenia rośnie potęga państwa. Ilustracja jest prosta: „zasięg i siła przebicia nowoczesnych dział przewyższaja skuteczność kuszy [...] prędkość dzisiejszych pojazdów - szybkość koni” ${ }^{52}$. Religijne kłótnie, zdaniem Schmitta, wywołały potrzebę wypracowania neutralnego obszaru, „na którym można by się porozumieć, a przynajmniej znaleźć jakiś kompromis, przynajmniej nieco spokoju, bezpieczeństwa i porządku" "33. Technologia i nauka to obszary, potencjalnie przynajmniej, neutralne. Autor Romantyzmu politycznego jako przykład powyższych tez wskazuje Prusy Fryderyka Wielkiego jako „idealny przykład mechanizmu ożywionego osobą suwerena" ${ }^{54}$.

W dalszej części rozważań Schmitt poddaje pod namysł kwestię prawa. Ta zaś może się okazać czymś kluczowym, gdy chodzi o prześledzenie różnicy między „technicznym państwem neutralnym a wspólnotą średniowieczną", która jest - jednym słowem - „ogromna" ${ }^{55}$. Podstawą średniowiecznego porządku, rządów władców, którzy nie byli absolutnymi posiadaczami auctoritas i potestas, było prawo zewnętrzne wobec tak króla, jak i ludu. Innymi słowy: „czymś oczywistym było feudalne bądź stanowe prawo sprzeciwu wobec władcy, który działa bezprawnie" ${ }^{\text {,56 }}$. Ową instancją odwoławczą było prawo boskie. Lewiatan formuły prawa boskiego odrzuca, w jego miejsce stawiając nieograniczoną - jak rzekliśmy: odpowiadającą protestanckiej wizji Boga - władzę suwerena. Nowoczesne państwo nie tylko jest w stanie zniszczyć wszelki opór dzięki swej technologii i sile, ale wręcz „prawo do oporu jako prawo stojące na jednym poziomie z prawem państwowym jest pod każdym względem, faktycznym oraz jurydycznym, czystym niepodobieństwem i absurdem" ${ }^{\text {"57 }}$. Poruszając się w obrębie logiki nowoczesnego państwa - państwa, które samo nakłada prawa, a więc koniecznością dla niego jest zaistnienie i zastosowanie pozytywistycznie uj-

\footnotetext{
Tamże, s. 47.

Tamże, s. 53.

Tamże, s. 55.

Tamże, s. 57.

Tamże, s. 59

Tamże, s. 60.

Tamże.
} 
mowanej drogi procesu legislacyjnego - widzimy, że potencjalny opór nie znajduje żadnego uzasadnienia dla swego zaistnienia. „Prawo do protestu jest utopijne”, a więc Lewiatan „funkcjonuje jako niezniszczalne narzędzie zaprowadzania spokoju, bezpieczeństwa i porządku, mając całe obiektywne i subiektywne prawo po swojej stronie, skoro jako jedyny i najwyższy prawodawca jest samym źródłem wszelkiego prawa" ${ }^{, 58}$. W ten oto sposób, jak uważa Schmitt, stan natury zostanie przeniesiony na poziom stosunków międzynarodowych. Jego podmiotami są twory o odpowiednim stopniu organizacji technicznej, nie zaś sami ludzie. „Źródło porządku państwowego znajduje się wewnątrz państwa" ${ }^{\text {"59 }}$. Jak mogłoby się wydawać, całkowite neutralizacja i pokój na ziemi mogłyby nastąpić dopiero w momencie zupełnego pozbycia się stanu natury ze świata, a więc powstania nowoczesnego państwa o globalnym zasięgu ${ }^{60}$.

Zmiany ładu instytucjonalnego wynikały zarazem z dążeń do zaprowadzenia i utrwalenia rozstrzygnięć normatywnych już podjętych w ramach spekulacji filozoficznej, zatem pomyślanych. Rezygnacja ze sporów teologicznych i postawienie na technikę może być pewnym aspektem neutralizacji, nie wykorzeni jednak z umysłów „odwiecznych”, a więc mających swe zaczepienie w sferze egzystencjalnej, zakorzenionych w naturze człowieka pytań - o śmierć, o dobre życie i jego sens - a przynajmniej nie zredukuje ich do stopnia, w którym przestaną zagrażać porządkowi w państwie. Schmitt, wychodząc od rozdziału 37 Leviathana, pokazuje, że wyłom nastąpił na poziomie „wiary w cuda". Hobbes przyjmuje postawę agnostyka. Oświecenie, które całkiem odrzuci wiarę w cuda jako zabobon, następuje wraz z przyjęciem zasady Auctoritas non Veritas. Skoro „nic nie jest prawdziwe, a wszystko jest rozkazem" - podkreślmy: rozkazem suwerena - „ostatecznie to [władca] decyduje, co jest cudem w jego państwie" ${ }^{\text {"61 }}$. Podział na wnętrze i zewnętrze, „publiczne wyznanie i wewnętrzną wiarę", został jednak dokonany nie przez angielskiego myśliciela, lecz przez Barucha Spinozę. Już same tytuły 19 i 20 rozdziału jego Traktatu teologiczno-politycznego wiele nam mówią: Wykazanie, że władze najwyższe mają najzupetniej prawo stanowienia w zakresie spraw duchowych i że zewnętrzny kult religijny powinien być przystosowany do spokoju pań-

\footnotetext{
Tamże, s. 60-61.

Tamże, s. 62.

Podobnego typu rozważania znajdziemy chociażby w książce Straussa 0 tyranii (zob. L. Strauss, O tyranii, Kraków 2009), osobliwie w „publicznej i prywatnej debacie”, jaką odbył on z Alexandrem Kojèvem. Zob. A. Kojève, Wstęp do wykładów o Heglu, przeł. Ś. F. Nowicki, Aletheia, Warszawa 1999. Zob. też: L. Strauss, Prawo naturalne w świetle historii, przeł. T. Górski, Warszawa 1969; P. Sloterdijk, Pogarda mas. Szkic o walkach kulturowych we wspótczesnym społeczeństwie, przeł. B. Baran, Warszawa 2003.

Tamże, s. 70.
} 
stwowego, jeżeli mamy być posłuszni Bogu w sposób właściwy ${ }^{62}$ oraz Wykazanie, że w państwie wolnym każdemu wolno myśleć, co mu się podoba, i mówić, co myśli ${ }^{63}$. Tak oto Hobbes - w parze ze Spinozą - mogą się nam jawić jako prawdziwi ojcowie liberalizmu ${ }^{64}$. To początek ,prawnie skonstruowanej nowoczesnej, indywidualistycznej wolności myśli i sumienia, a wraz z tym jednostkowych swobód, charakterystycznych dla struktury liberalnego systemu konstytucyjnego" $"$.

W ten oto sposób Lewiatan, jakiego poznaliśmy, umiera. „Władza wyłącznie publiczna i zewnętrzna jest pusta" ${ }^{66}$ - to naturalne konsekwencje przesunięcia jej „do środka”. Nie wolno jednak sądzić, że Lewiatan znika. Zanika suweren, będący już tylko i wyłącznie jako pustą formą. Cały mechanizm władzy - „dobrze zorganizowana egzekutywa, armia i policja, aparat administracyjny i sądowniczy, sprawnie działająca, profesjonalna biurokracja" $^{67}$ - pozostają i czekają na wyłonienie się nowego władcy. Niektórzy socjologowie, których przywołuje Schmitt - na przykład Max Weber - uważali, że owym nowym władcą będzie właśnie „profesjonalna biurokracja”, rządząca w „zracjonalizowanym porządku współczesnego państwa" "68 , w sposób legalny, bazując na nowoczesnej, pozytywistycznej legislaturze, która dawno zrzekła się "boskiego, naturalnego bądź innego przedpaństwowego prawa" Gdy w taki sposób ujmiemy nowoczesne państwo „zaprogramowane” przez Hobbesa, jako z góry nastawione na ewolucję od monarchii absolutnej po ład liberalno-demokratyczny, a więc nastawione od początku do końca na opiekę nad własnymi obywatelami, których summa summarum ma ono chronić odeprzemy zarzut Johna Locke'a, zgodnie z którym „,biedne ludzkie indywidua wyrywa się z absolutnego przerażenia w stanie natury tylko po to, by

\footnotetext{
Tamże, s. 321. Prawo naturalne...

B. Spinoza, Traktaty, przeł. I. Helpern-Myślicki, Kęty 2003, s. 309.

Podobne uwagi formułował Leo Strauss w artykule On a Forgotten Kind of Writing. Czytamy, że: „His [Spinoza] whole enterprise consists of what one might call an open attack on all forms of orthodox Biblical theology. He could dare to make this attack because he could count, within certain limits, on the sympathy of those who regarded the moral teaching, as distinguished from the teaching about dogma and ritual, as the chief teaching of divine revelation as accessible in the Bible. The explicit theses of the Theologico-Political Treatise may be said to express an extreme version of the «liberal» view. [...] Spinoza attempted to appease not any orthodox theologians but those who were more or less inclined toward a liberal Christianity. He concealed his partial, but decisively important, disagreement not with the orthodox theologians but with liberal believers of various shades". Zob. L. Strauss, On a Forgotten Kind of Writing, „Chicago Review” 1954, Vol. 8, No. 1, s. 69. Zob. także: L. Strauss, 
wepchnąć je w podobnie wszechogarniający lęk przed władzą Molocha i Golema" ${ }^{, 70}$. Zgodnie z tą sugestią należałoby wskazać, że wraz z zapanowaniem współczesnego ładu znika polityka w mocnym sensie, jaki nawet dziś lansowany jest w jej definicjach: mianowicie jako działalność, której celem jest zdobycie władzy ${ }^{71}$. Ta byłaby niczym innym jak tylko „nadzorowaniem” administracji. Polityka jako taka zanikłaby, skoro przestałaby istnieć władza w jej chociażby XVIII-wiecznym znaczeniu.

Tu kończy się zasadnicza treść książki. W ostatnim rozdziale Schmitt rozważa jeszcze zróżnicowanie $\mathrm{w}$ angielskim systemie polityczno-prawnym, który z początku odrzuca koncepcje Hobbesowskie - chciałoby się rzec: nikt nie jest prorokiem we własnym kraju. W świecie XX wieku różnice się zacierają. Wykład z historii idei dał nam podstawy do tego, by sposób patrzenia na nowoczesne państwo, z jego założeniami i konsekwencjami, wykorzystać po raz wtóry i przyłożyć jako czytelną strukturę do wskazań, które znajdziemy w innych tekstach, a które, jak się okaże, zadziwiająco bliskie są wskazaniu z początkowego przypisu ${ }^{72}$. „Antychryst króluje na Lewiatanie”, powiada Schmitt nie wprost, by w innym miejscu wrócić do tego zdania z całą mocą. Sam Lewiatan... pokazuje, jak dokładnie myśl niemieckiego jurysty przenicowała nowoczesne struktury państwowe, jawiące mu się jako wprawiające $\mathrm{w}$ ruch procesy mechanizacji, neutralizacji, pacyfizmu, technicyzacji, wreszcie: uniwersalizacji i homogenizacji.

Najważniejszym rozmówcą Schmitta, którego wagi dla filozoficznopolitycznego namysłu XX wieku nie trzeba chyba udowadniać, był Leo Strauss. O ile podstawowym pojęciem, z którym kojarzy się nazwisko autora Pojęcia polityczności, jest właśnie „polityczność”, o tyle postać amerykańskiego filozofa polityki należy wiązać z tzw. problemem teologicznopolitycznym. Tego typu podejście na zachodzie jest obecnie przyjmowane m.in. przez Heinricha Meiera, natomiast w Polsce kluczowym dla swoich rozważań nad spuścizną Straussa uczynił je Paweł Armada. W najprostszych słowach: problem teologiczno-polityczny odnosi się do wzajemnej relacji władzy boskiej i ludzkiej. Jak pisze Strauss, „, nie ma alternatywy o znaczeniu bardziej podstawowym niż ta: przewodnictwo ludzkie albo Boskie" ${ }^{\text {,3 }}$. Dla Straussa nowoczesność stanowi nade wszystko próbę rozwiązania problemu teologiczno-politycznego - problemu religijnych fundamentów prawa bądź wspólnot politycznych. Schmitt stawia sprawę w podobny sposób. U samego

Tamże, s. 93.

Zob. A. Heywood, Politologia, przeł. B. Maliszewska, M. Masojć, N. Orłowska, D. Stasiak, Warszawa 2006, s. 4-15.

Zob. C. Schmitt, Lewiatan..., s. 16, p. 11.

L. Strauss, Prawo naturalne w świetle historii, przeł. T. Górski, Warszawa 1969, s. 73. 
źródła Hobbesowskiej koncepcji leży „walka z typowymi doktrynami judeochrześcijańskimi”, zaś nowoczesne państwo „kładzie kres teologicznym spekulacjom i subtelnościom ze strony żądnych władzy kapłanów i sekciarzy" ${ }^{, 74}$. Dominacja techniki w sposób bezwzględny niweluje wszelkie religijne podziały, które stają się „,bezprzedmiotowe”. Lewiatan wobec tego jawić nam się musi jako „wielki symbol walki [...] przeciwko wszelkim formom teologii politycznej" ${ }^{75}$. Powstanie ostatniego, nowoczesnego państwa jako efektu rozwoju techniki i postępu w neutralizacji, zwiastowane przez tylu myślicieli, dla Schmitta - który ów rozwój opisuje w swoim artykule Epoka neutralizacji i apolityzacji - jest momentem, kiedy zanika możliwość zaistnienia „różnicy, która sensownie uzasadniałaby konieczność poświęcania własnego życia”, jako że ów moment jest równoznaczny z narodzinami „globu ziemskiego bez reszty ogarniętego ideą pacyfizmu - świata bez różnicy między przyjacielem i wrogiem, a zatem świata pozbawionego polityki" ${ }^{76}$. Polityczność - taka, jak rozumie ją Schmitt, czyli "rozróżnienie przyjaciela i wroga" - wraz z zapanowaniem neutralnego ładu liberalno-demokratycznego „zanika w ekonomii lub w technice albo też rozpływa się w wiecznej rozmowie kulturalnych i historiozoficznych ogólności, która tworzy nasze dzisiejsze estetyczne wyobrażenia",

W swych Uwagach do „Pojęcia polityczności”... Leo Strauss, komentując sposób myślenia autora Nomos der Erde, pisze, że „liberalizm zabił więc nie tyle samą polityczność, ile rozumienie polityczności [...]. Żeby rozproszyć mgłę, w jaką liberalizm spoił rzeczywistość, pokazać trzeba, że polityczności jako takiej po prostu nie da się z rzeczywistości wyrugować" ".9 . Schmitt, występując z pozycji historyka idei, nie przeistacza się w beznamiętnego intelektualistę, który nie robi nic innego, jak tylko omawia pewną partię materiału historyczno-filozoficznego. Nie jest antykwariuszem. Analizując instytucje nowoczesnego państwa prawa - i zarazem pisząc o polityczności, decyzjoniźmie, neutralizacji i technicyzacji - nie staje się jego teoretycznym apologetą. Wręcz przeciwnie. Jak zauważa autor The City and the Man, ,afirmacja polityczności jako takiej nie może być ostatnim słowem Schmitta przeciwko liberalizmowi; być może stanowi ona tylko przygotowanie do radykalnej krytyki liberalizmu”. Polemika, którą podejmuje Schmitt, „ma je-

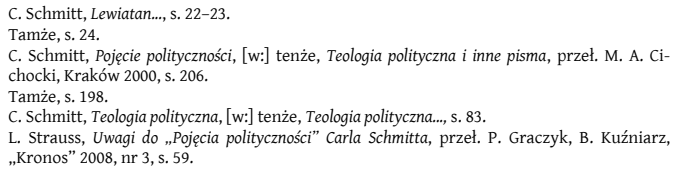


dynie przygotować pole rozstrzygającej bitwy między „duchem techniki”, to jest „masowym ruchem antyreligijnego, skupionego na doczesności aktywi$\mathrm{zmu}^{180}$ [79], a duchem i wiarą przeciwną, która, jak pisze Strauss - celowo nie dopowiadając treści, a więc przeinaczając intencje autora Teologii politycznej - ,jak się wydaje, nie ma jeszcze nazwy" ${ }^{81}$.

Wydawać by się mogło, że artykuł Straussa nie obejmuje pewnych wątków fundamentalnych dla Schmitta m.in. ze względu na brak wskazania moralno-egzystencjalnej proweniencji tychże. Po pierwsze nazwa kluczowego elementu, „ducha i wiary przeciwnej”, zostaje przez niego pominięta. Po drugie słowa otwierające i kończące artykuł („rozprawa Schmitta poświęcona jest pytaniu o "porządek ludzkich spraw» [81], tzn. o państwo" ${ }^{{ }^{82}}$ oraz „[Schmitt] spodziewa się nadejścia porządku ludzkich rzeczy ze strony «integralnej wiedzy» [81]"33) sprawiają wrażenie, jakby intencją Schmitta nie było nic innego, jak tylko zaprowadzenie ostatecznego porządku sytuującego się w obrębie nowoczesnego państwa. Porządek ten, mający swe źródło w „integralnej wiedzy” (co brzmi niemal tak samo jak Heglowska „wiedza absolutna”, „samowiedza” - czyli „wiedza o całości” spraw ludzkich, wiedza pewna, jednak wynikająca nie z rozpoznania zasady jednoczącej wszechrzecz, co dawałoby człowiekowi wiedzę na temat właściwego mu miejsca w kosmosie, ale z historycznego i racjonalnego rozwoju ludzkości, któremu nie da się zaprzeczyć ani którego nie da się zanegować), byłby - wbrew rzeczywistym intencjom niemieckiego prawnika - pacyfistycznym, neutralizującym, technicznym ładem, któremu Schmitt się przecież sprzeciwia. Zarzut Straussa, który uważa, że „Schmitt trwa przy kategoriach moralnych stworzonych przez swoich rywali, zamiast podać $\mathrm{w}$ wątpliwość pretensje moralności humanitarno-pacyfistycznej do miana moralności" ${ }^{84}$ jest nie do utrzymania, skoro rzeczy zostaną nazwane po imieniu. Prawdziwa walka toczy się nie między wspólnotami, państwami, czy nawet ludźmi samymi w sobie, nie interesującymi się rzeczami zewnętrznymi wobec nich, ale między Bogiem a

so Autor przekładu artykułu Straussa opublikowanego w „Kronosie” nie podjął się uzupełnienia cytatów z polskich przekładów, tłumacząc się wynikającą z tego potencjalną nieprzystawalnością sformułowań do oryginalnego wywodu amerykańskiego myśliciela. Zaopatrzone numerami 79, 80 i 81 cytaty Straussa nie odnoszą się jednak, jak mógłby wskazywać tytuł, do samego Pojęcia polityczności, lecz do dodatku, obecnego w wydaniach po 1931 roku, o tytule Epoka neutralizacji i apolityzacji. Wywody Straussa pozostawiono bez zmian, jednak przy zastosowaniu cytatów z ww. tekstu dla informacji czytelnika należy zaznaczyć, że sytuują się one na stronach 442, 443 i 444, a ich forma różni się tylko nieznacznie. Każdy taki cytat oznaczony zostanie osobną adnotacją w przypisie.

L. Strauss, Uwagi..., s. 72.

Tamże, s. 58 .

Tamże, s. 72.

Tamże, s. 71. 
Antychrystem. „Afirmacja polityczności”, jak chciałby tego Strauss, nie jest zatem „abstrahująca od ocen moralnych”, przez co nie „zachowuje się neutralnie wobec wszystkich podziałów na przyjaciół i wrogów" ${ }^{15}$, stając się czymś niemalże tożsamym z liberalizmem. Schmitt mówi jasno: „chodzi o przeciwieństwo dobra i zła, Boga i szatana, między którymi toczy się walka na śmierć i życie” ${ }^{86}$."Duch i wiara przeciwna” nie są tedy niczym innym, jak zastępami ludzi, którzy walczą z Antychrystem w imię obrony i zachowania człowieczeństwa. Piotr Graczyk napisał we wspomnianym wcześniej artykule - a jego spostrzeżenie w tym kontekście wydaje się nad wyraz celne - że „potrzebujemy, według Schmitta, nie tyle króla-filozofa, ile raczej Katechona, który poprowadzi nas do boju z Szatanem" ${ }^{87}$.

W swoim artykule Epoka neutralizacji i apolityzacji, wygłoszonym na kongresie Europejskiego Związku Kultury w Barcelonie w roku 1929, Schmitt proponuje kolejną, acz komplementarną z powyższą, analizę dziejów ludzkiej myśli. Te, począwszy od wieku XVI, dzielą się na cztery stadia, „przechodząc od tego, co teologiczne, do metafizyki, stamtąd do sfery humanitarno-etycznej i wreszcie do tego, co ekonomiczne" ${ }^{98}$. Innymi słowy: chodzi o ujawniające się w ciągu ostatnich stuleci tendencje do „estetyzmu”, ,wysublimowanej konsumpcji i przyjemności”, będące „najpewniejszą i najwygodniejszą drogą" do „powszechnej ekonomizacji życia umysłowego i do takiej konstytucji umysłowej, która w produkcji i konsumpcji odnajduje centralne kategorie ludzkiej egzystencji" ${ }^{, 89}$. Całość przemian zostaje zdominowana w wieku XIX przez niesamowite tempo rozwoju technologicznego. Swoista wiara w technikę sprawiła, że „problemy moralne, polityczne, społeczne i ekonomiczne" ", stały się obojętne, a raczej: poczucie problematyczności zostało zastąpione przez zawierzenie technice jako tej, która pozwoli w przyszłości rozwiązać wszystkie kwestie. Każda kolejna epoka jawi się jako posiadająca odpowiedzi na problemy właściwe epokom poprzednim, w dla siebie tylko charakterystycznej przestrzeni ducha, dzięki „postępowi w oświeceniu” ${ }^{91}$. Wytłumaczenie, które padło już wcześniej, mianowicie: „po beznadziejnych teologicznych dysputach i sporach XVI stulecia [...] poszukiwanie neutralnego obszaru, w którym ucichłyby sporu i gdzie można by się

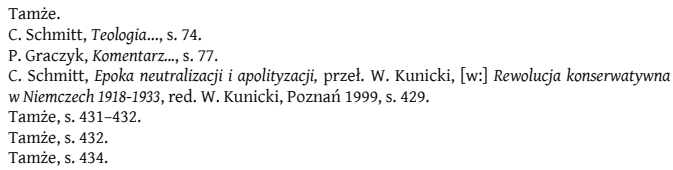


porozumieć, pogodzić i nawzajem przekonać" ${ }^{92}$ - stało się przyczynkiem do stopniowej, jak w tytule, neutralizacji i apolityzacji. Autor Politycznego romantyzmu pisze, że „wraz z techniką odnaleziono ostatecznie zneutralizowaną opokę”, która „służy każdemu”, a wobec „problemów teologicznych, metafizycznych, moralnych, a nawet ekonomicznych, które mogą być przedmiotem wiecznych sporów, [...] ma w sobie coś orzeźwiająco rzeczowego" ${ }^{\text {"93 }}$.

Technologia różni się jednak od sfer, które objęła: „jest zawsze tylko instrumentem i bronią, a jako że wszystkim służy, [...] nie jest neutralna" ${ }^{94}$. Technika sama „pozostaje ślepa”, „technicy ani nie odgrywają przywódczej roli w ekonomice, ani nie rządzą gospodarką". Jest ona tylko i wyłącznie środkiem, jaki wypracowało sobie nowoczesne państwo, pragnące stać się globalnym, jednolitym, uniwersalnym tworem. W Pojęciu polityczności Schmitt wyraża opinię, że „teza o «wszechmocnym» państwie jest w rzeczywistości rezultatem dość powierzchownej sekularyzacji teologicznych formuł o omnipotencji Boga”, a - to już Teologia polityczna - „wszystkie istotne pojęcia z zakresu współczesnej nauki o państwie to zsekularyzowane pojęcia teologiczne" ${ }^{96}$. Nic w tym dziwnego - wyobrażenie czegoś istotowo odrębnego od człowieka, czegoś, co go przekracza, lecz jednocześnie ogarnia, co jest wszechmocne, przy tym jednolite, trwałe i niezmienne, musi kojarzyć się z wyobrażeniem Boga - „mamy do czynienia z niewytłumaczalną jednością państwa, które jest prawodawcą, wykonawcą praw, strażnikiem, instancją łaski i zarazem opiekunem”" "Dzisiaj nie ma nic bardziej nowoczesnego niż walka z politycznością" ${ }^{98}$, powiada Schmitt, piętnując neutralizujące, pacyfistyczne, apolityczne efekty powstania nowoczesnego państwa. Jak pamiętamy, to dziełem Spinozy było stworzenie „procedury nowożytnej nauki w jej pierwotnej koncepcji - uczynienie świata całkowicie przejrzystym i wyraźnym, możliwym do pełnego zmatematyzowania bytem" ". To nic innego jak cel nowoczesnej technologizacji i „unaukowienia” świata: uczynić z niego matematyczną (nie metafizyczną!) całość. Jednak technika, jak przekonuje Schmitt, przeraża. „Europejskie stulecie, które skarży się na maladie du siecle, oczekując władztwa Kalibana albo After us the Savage God, zamyka pokolenie Niemców, które podnosi skargę na bezduszną epokę techniki, gdzie dusza

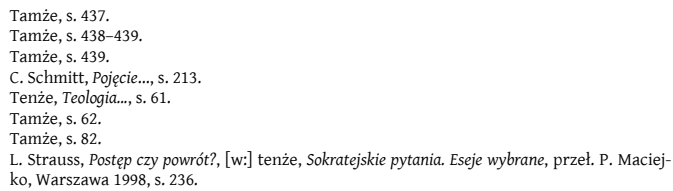


jest bezradna i bezsilna”. Ów niezidentyfikowany lęk przed (jak powinno się wydawać - zbawienną!) technologią „wyrastał z niejasnego przeczucia konsekwencji doprowadzonego już do końca procesu neutralizacji” ${ }^{, 00}$.

Według tego, jak poglądy Schmitta rekonstruuje Heinrich Meier, ,antyreligijność technologii ma religijny wymiar. „Wiara w technologię” nie jest neutralna. Została ufundowana na odwróceniu się od prawdziwej religii" Postępującemu ujednolicaniu świata, który stał się „kompletnie zdepolityzowany i zneutralizowany", zdaniem Schmitta może zapobiec tylko i wyłącznie fakt „nieuchronności polityczności” ${ }^{, 102}$ - przyjęcie tej tezy wymaga jednak, aby „spór o polityczność” dotyczył rzeczy zakorzenionych w naturze ludzkiej, a więc niezależnych od naszych historycznych zmagań. Bowiem historia, o czym możemy się przekonać, prowadzi do powstania „państwa światowego”, któremu Schmitt się sprzeciwia, „uznając [go] za anty-boskie przedsięwzięcie zbudowania raju na ziemi” ${ }^{103}$. Schmitt zna swojego (uniwersalnego?) wroga - „w opisie ideału kompletnie spacyfikowanego globu, świata bez polityki, życia bez powagi, Schmitt walczy z imperium Antychrysta” $^{{ }^{104}}$. Poetyckość, a i pewna enigmatyczność Schmittowskiego opisu naszej sytuacji przywodzą na myśl wywody Heideggera na temat „przezwyciężenia metafizyki” czy „zapomnienia o byciu”. Przytoczymy tu większą część opisu Schmitta: „duch tego, co techniczne, który doprowadził do masowej wiary antyreligijnego aktywizmu doczesności, jest duchem być może złym i szatańskim, ale nie takim, którego można zanegować jako coś mechanicznego, jako coś, co należy do samej techniki. Jest być może czymś straszliwym, ale w swej istocie nie jest techniczny i maszynowy. Jest przekonaniem aktywistycznej metafizyki, wiarą w nieograniczoną moc i panowanie człowieka nad naturą, a nawet nad ludzką physis, w bezgraniczne "cofanie się barier naturalnych», w bezgraniczne zmiany i uszczęśliwianie naturalnie doczesnego bytu człowieka. Można to określać jako fantastyczne i szatańskie, ale nie po prostu jako martwą, pozbawioną ducha lub mechaniczną bezdusznośćn ${ }^{105}$.

$\mathrm{W}$ ten oto sposób rozpoczęcie pocesów neutralizacji i depolityzacji, o których mówi Schmitt, a których efektem jest erupcja rozwoju technologicznego, powstanie państwa będącego maszyną, którego tor został wytyczony, przez co nie potrzebuje ono przywódcy, ale administratora, nadzorującego zachodzące $\mathrm{w}$ nim procesy - w nieznacznej tylko mierze regulując drogę rozwoju, wyznacza moment, w którym „Antychryst zaczął budować

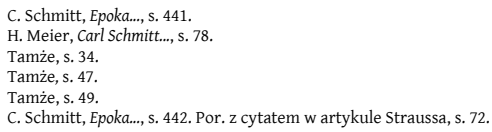


swoje imperium" ${ }^{106}$. Zmiany, które zachodzą, nie są rozumiane jako coś złego. Zło od czasów Hobbesa i Spinozy jest już bowiem tylko i wyłącznie cechą natury ludzkiej, którą należy przezwyciężyć jako „ludzką ułomność albo jako zwierzęca siłę, jako humana impotentia albo naturae potentia (Spinoza, Eth. III praef.)" ${ }^{107}$, nie zaś ruchem ludzkiego ducha, który odwraca się od tego, co boskie. Jak pisze Heinrich Meier, „Antychryst może zatriumfować - i na dłuższą metę może zatriumfować tylko wówczas - jeżeli uda mu się przekonać ludzi, że opozycja przyjaciela i wroga została przezwyciężona raz i na zawsze, że nie muszą już dłużej wybierać pomiędzy Chrystustem i Antychrystem"108. Stan natury Schmitta, którego zdaje się potrzebować do „realizacji” polityczności, a który wymyka się nam coraz bardziej, zostaje scharakteryzowany również zdaniem Straussa nieco inaczej niż u autora Leviathana. Afirmując polityczność, afirmujemy „stan wojny między grupami” ${ }^{109}$, nie zaś między pojedynczymi ludźmi. Spór nie jest indywidualistyczny, lecz kosmiczny - to spór w ramach zbioru politycznych jedności, których moment założycielski to nie umowa, ale opowiedzenie się za dobrem bądź złem - a konsekwencje jego zakończenia będą wspólne dla całego świata. „Duch prowadzi walkę przeciwko duchowi, życie przeciwko życiu, a z sił integralnej wiedzy powstaje ład ludzkich spraw. Ab integro nascitur ordo" ${ }^{\text {"110 }}$. Zagadką pozostaje źródło, z którego należałoby czerpać wiedzę - wiedzę integralną - na temat tegoż ładu.

Jak napisał Mark Lilla, „,w świetle najnowszych ujęć jego myśli, Schmitt okazuje się [...] (zależnie od skłonności) albo klasycznym teoretykiem politycznym, który bada podstawy polityki bez liberalnych złudzeń moralnych, albo demaskatorem liberalnej hipokryzji i ideologii" ${ }^{, 11}$. Spojrzenie na motywację egzystencjalno-moralną pozwoliło nam zrozumieć nastawienie Schmitta raczej na problem teologiczno-polityczny niż samą kwestię ustaleń normatywnych mających swe odzwierciedlenie w ładzie instytucjonalnym. Ład ludzkich spraw, do walki o który zdaje się wzywać Schmitt, musi być jednak czymś innym od tego, który został nam zaproponowany w wyniku spekulatywnych rozważań filozoficznych autorstwa Thomasa Hobbesa. Współczesne państwo, które stało się - cytując Webera - „wielką fabryką", w której zracjonalizowane zostało wszystko, „państwo totalne”, które „kolo-

\footnotetext{
H. Meier, Carl Schmitt..., s. 48.

L. Strauss, Uwagi..., s. 67.

H. Meier, Carl Schmitt..., s. 49.

L. Strauss, Uwagi..., s. 62.

C. Schmitt, Epoka..., s. 444. Por. z cytatem w artykule Straussa, s. 72. Łac. „porządek rodzi się z odnowy".

M. Lilla, Lekkomyślny..., s. 60.
} 
nizuje każdą dziedzinę i każdy obszar życia”" ${ }^{112}$, jak wskazaliśmy wcześniej, nie jest abstrakcyjnym tworem złożonym ze znalezionych $w$ antykwariacie idei - tylko czymś, co Schmitt, jak się wydaje, pojmował jako spełniające się diaboliczne „tu i teraz”, jako coś o ogromnym wpływie na życie człowieka nowoczesnego.

J A K U B C H M E L N I A K 